\title{
METHOD OF CALCULATION OF SOCIAL BENEFITS
}

\author{
Radosław WOLNIAK \\ Politechnika Śląska, Wydział Organizacji i Zarządzania, Instytut Ekonomii i Informatyki; rwolniak@polsl.pl, \\ ORCID: 0000-0003-0317-9811
}

Purpose: The aim of this publication is to present the methods currently in force in Poland for determining the amount of social benefits.

Design/methodology/approach: Qualitative and quantitative secondary data analysis. Data were collected from governmental organization reports and analyzed using Excel.

Findings: It can be stated that the social assistance system in Poland benefits from statistics on the prices of goods and services and the cost of living of households according to the number of households and their age. Thanks to these data, it is possible to determine the value of the minimum subsistence level, the minimum subsistence level, the WDR threshold and the Social Intervention Threshold. The values of these indicators are set in different time horizons the minimum subsistence level on a monthly basis, and the GVA level once every 3 years. In this way, the state authorities determine the income criterion entitling individuals to receive social assistance benefits.

Originality/value: Detailed calculations and summaries of the Income Support Threshold and Social Intervention Threshold for different social groups were made.

Keywords: social welfares, social benefits, social economy, social responsibility, labor market.

Category of the paper: research paper.

\section{Introduction}

Social policy generally aims at social progress, therefore its activities relate to work, living conditions, culture and social order. Social policy activities are therefore extremely diverse they include the labour market, family assistance, health care, education, housing and many other areas (Czajka, 2019). Such policy is conducted both by central authorities, i.e. the government, as well as local governments or non-governmental organizations (associations, foundations, etc.). Social policy is also a part of social responsibility (Wolniak, 2013, 2016, 2017, 2018; Wolniak, and Hąbek, 2016; Hąbek, and Wolniak, 2013, 2016; Hys, and Wolniak, 2016; Ponomarenko et al., 2016). 
Social policy is a broader concept than the concrete social assistance that forms part of it. Several principles can be applied to the implementation of social policy. These are the principles of (Bochenek, 2018; Machelski, 2017; Maciejko, 2015):

- income criterion,

- equal opportunity criterion,

- subsidiarity criterion,

- efficiency criterion,

- developmental criterion.

The first of these principles is that social assistance should be provided to the poorest people, as there is no justification for supporting the wealthy who do not actually need such assistance because they can cope on their own (Firlit-Fesnak, and Szylk-Skoczny, 2017; Szyszka, 2014). The criterion of equal opportunities refers to the lack of preference for a particular social or professional group and granting it more assistance than other entitled persons. However, so-called positive discrimination is allowed here, i.e. favouring certain social groups if it is justified (e.g. the disabled). The criterion of subsidiarity, on the other hand, concerns the fact that social assistance should be provided when other forms of assistance are impossible to apply or their application will not bring such effectiveness (Szarfenberg, 2016; Kamiński, 2015; Olkiewicz et al., 2019). This should take into account the activities of non-governmental actors. In principle, the criterion of effectiveness is the introduction in each legal act or regulation of an evaluation criterion consisting in periodical examination of the effectiveness of the implemented policy and elimination of those forms that do not bring the expected results (Flaszyńska, 2018; Muszalski, 2015; Walc, and Szluz, 2008; Grebski, et al., 2019; Wolniak, et al., 2019; Wolniak, and Grebski, 2018; Wolniak, and Skotnicka-Zasadzień, 2018). The latter, the principle of the development criterion, refers to directing the social policy towards helping to get out of poverty and deprivation, and not towards sponsoring them. Accordingly, the recipients of the aid should be mobilized to undertake the work (Bragiel, and Badora, 2008; Broda-Wysocki, 2016; Pląsek, 2016; Haładus, 2019).

It follows from the above considerations that social policy is a broad concept, which is related to the wide variety of activities undertaken within its framework. The implementation of this policy requires the application of a number of principles, which every democratic state should take into account (Auleytner, 2004; Kokoszkiewicz, 2015; Koąłczkowski, and Ratajczak, 2014; Łojko, 2015, 2017).

Social assistance is about helping people, as well as whole families in a difficult life situation. It is also a situation in which these people would not be able to cope on their own even with their own powers, resources or abilities. Social assistance is an institution of social policy implemented by the state authorities (Rajski, 2016; Staręga-Piasek, 2016). The state creates appropriate persons and organisations for the enacting of social assistance, the task of which is to support citizens in meeting their essential needs, as well as to provide them with decent living conditions (Lewandowska, 2018; Łojko, 2015, 2017). 
The aim of this publication is to present the methods currently in force in Poland for determining the amount of social benefits.

\section{Results and discussions}

The right to receive social welfare benefits is based on an income criterion. The income thresholds are determined by establishing the social minimum and the minimum of existence on the basis of an expert-basket method. It consists in determining the value of basic needs (basket) and determining consumption patterns, as well as lifestyle (expert approach). Four different indicators are calculated in the Polish social welfare system:

- social minimum,

- a minimum of existence,

- social intervention threshold,

- family income support.

The minimum subsistence level is considered to be the threshold for intervention, which is the upper limit of the poverty area. In turn, the minimum subsistence is the minimum of poverty, i.e. the level of needs below which there is a threat to human life and development. It determines survival. The minimum subsistence level is determined for workers and pensioners. The data presented in the Social Policy Department refer to September 2018 and are based on average prices of consumer goods and services according to the data of the Central Statistical Office. These were such goods and services as:

- food,

- living quarters (use and energy, equipment),

- education,

- culture and recreation,

- clothes and shoes,

- health care,

- personal hygiene,

- transport and communications,

- other expenses.

The minimum subsistence level is shown in Table 1 . 
Table 1.

Minimum subsistence level in September 2018 and 2017 [PLN per person]

\begin{tabular}{|l|l|c|c|}
\hline \multicolumn{1}{|c|}{ Household } & \multicolumn{1}{|c|}{ Type } & $\begin{array}{c}\text { Minimum subsistence } \\
\text { level } \\
\text { September 2018 }\end{array}$ & $\begin{array}{c}\text { Minimum subsistence } \\
\text { level } \\
\text { September 2017 }\end{array}$ \\
\hline \multirow{5}{*}{ Employee household } & 1-person & 1166,78 & 1134,97 \\
\cline { 2 - 4 } & 2-persons & 954,29 & 938,32 \\
\cline { 2 - 4 } & 3- persons (M+K+DM) & 962,30 & 939,13 \\
\cline { 2 - 4 } & 3- persons (M+K+DS) & 1021,49 & 996,40 \\
\cline { 2 - 4 } & 4- persons & 926,22 & 908,62 \\
\cline { 2 - 4 } & 5- persons & 904,71 & 889,41 \\
\hline \multirow{5}{*}{ Pensioner household } & 1- persons & 1151,57 & 1123,30 \\
\cline { 2 - 4 } & 2- persons & 949,65 & 931,71 \\
\hline
\end{tabular}

Source: own elaboration based on the report: Poziom i struktura minimum socjalnego we wrześniu 2018 r., Instytut Pracy i Spraw Socjalnych, Warszawa, grudzień 2018.

The lowest minimum subsistence level is for members of a 5-person family (parents with three children), and the highest one for a single-person household. The difference between them was PLN 262.07 in 2018 and PLN 138.57 in 2017. Of this amount, the most is for housing and food - more than half, and the least for education - about $2 \%$. It is also noted that the social minimum in 2018 increased in comparison to the same period in 2016, which was influenced by price increases.

In turn, the subsistence minimum is calculated once a year, with data presented by voivodeship and city class. This minimum is treated as the minimum level for survival, i.e. the lower poverty line. The value of the minimum subsistence level in 2017 and 2016 is presented in Table 2.

Table 2.

Minimum subsistence in 2017 and 2016 [PLN per person]

\begin{tabular}{|l|l|c|c|}
\hline \multirow{2}{*}{ Household } & \multicolumn{1}{|c|}{ Type } & $\begin{array}{c}\text { Minimum subsistence } \\
\text { level } \\
\mathbf{2 0 1 7}\end{array}$ & $\begin{array}{c}\text { Minimum subsistence } \\
\text { level } \\
\mathbf{2 0 1 6}\end{array}$ \\
\hline \multirow{5}{*}{ Employee household } & 1-person & 574,01 & 555,02 \\
\cline { 2 - 4 } & 2-persons & 483,40 & 467,27 \\
\cline { 2 - 4 } & 3-persons (M+K+DM) & 465,45 & 449,86 \\
\cline { 2 - 4 } & 3-persons (M+K+DS) & 507,42 & 490,83 \\
\cline { 2 - 4 } & 4-persons & 488,60 & 472,04 \\
\cline { 2 - 4 } & 5-persons & 502,22 & 485,38 \\
\hline Pensioner household & 1-persons & 544,03 & 527,30 \\
\cline { 2 - 4 } & 2-persons & 453,41 & 439,55 \\
\hline
\end{tabular}

Source: (Haładus, 2019).

In 2017, the lowest level of the minimum subsistence level is for 3-person household and the highest for 1-person household. The difference between the social minimum and the minimum subsistence level for a family of one-person employees is 592.77 PLN. In comparison to 2016, however, there is an increase in the subsistence minimum, which indicates a growing cost of living of households. This is a result of inflation and rising prices of products and services. In 2016 for a 3-person household the minimum subsistence rate was 490.83 PLN, so compared to 2017 it was 16.56 PLN lower. 
Thanks to updating the prices of the basket of goods and services, it is also possible to establish Family Income Support. This study differentiates between different types of households depending on the number of children and their age:

- younger children aged 0-5 years,

- children growing up between the ages of 6-18,

- older children aged 19-24.

The types of households included in this survey are presented in Table 3.

Table 3.

Households subject to examination under the Family Income Support threshold

\begin{tabular}{|l|l|}
\hline \multicolumn{1}{|c|}{ Household } & \multicolumn{1}{c|}{ Type } \\
\hline single parent & $-\quad$ parent with a younger child (M/K DM), \\
& $-\quad$ parent with an adolescent child (M/K DD), \\
& $-\quad$ parent with a child with disabilities (M/F DDN) \\
\hline parents with one child & $-\quad$ with one younger child (M/K DM) \\
& $-\quad$ parents with one child growing up (M/K DD) \\
\hline parents with two children & $-\quad$ with 2 younger children (2DM), \\
& $-\quad$ of 2 children growing up (2 DD), \\
& $-\quad$ with 2 older children (2DS), \\
& $-\quad$ with 2 children younger and growing up (DM+DD), \\
& $-\quad$ with a younger and disabled child growing up (DM+DDN), \\
& $-\quad$ with a child younger and older (DM+DS), \\
& $-\quad$ with an adolescent and older child (DD+DS.) \\
\hline parents with three children & $-\quad$ parents with 3 children of different ages, \\
& $-\quad$ parents with four children (1 younger, 2 growing up, 1 older) \\
\hline
\end{tabular}

Source: (Haładus, 2019).

The Family Income Support Threshold is set every 3 years - the latest data are for 2016 and are valid until 2019. The amount of this threshold is presented in Table 4.

\section{Table 4.}

Family Income Support Threshold in 2016

\begin{tabular}{|l|c|}
\hline The family & WDR threshold [PLN] \\
\hline single parent with DM & 797,5 \\
\hline single parent with DD & 850,1 \\
\hline single parent with DDN & 858,3 \\
\hline parents with DM & 762,0 \\
\hline parents with DD & 797,1 \\
\hline parents with DM i DD & 751,9 \\
\hline parents with DM i DDN & 759,7 \\
\hline parents with DM i DS. & 760,6 \\
\hline parents with DD i DS. & 792,5 \\
\hline parents with 2 DM & 725,6 \\
\hline parents with 2 DD & 778,2 \\
\hline parents with 2 DS. & 806,8 \\
\hline parents with DM, DD i DS. & 750,6 \\
\hline parents with DM, 2 DD i DS. & 737,6 \\
\hline
\end{tabular}

Source: (Haładus, 2019). 
The highest WDR threshold was calculated for a lone parent with an adolescent child and for a lone parent with an adolescent child with a disabled child - the threshold exceeds PLN 850 per person. In turn, the lowest WDR threshold was determined for parents with two younger children - PLN 725.6 per person and for parents with two adolescent children and an older child - PLN 737.6 per person.

The last category, which is calculated using the basket and expert method in the Polish social welfare system is the Social Intervention Threshold. This means the level from which one can acquire entitlement to social welfare benefits. The level at 2016 prices is presented in Table 5 .

Table 5.

Social Intervention Threshold

\begin{tabular}{|l|l|c|}
\hline The family & WDR threshold [PLN] & Social Intervention Threshold [PLN] \\
\hline pensioners' & 2-persons & 593,4 \\
\cline { 2 - 3 } & 1-persons & 717,3 \\
\hline household of a single parent & single parent with DM & 550,5 \\
\cline { 2 - 3 } & single parent with DD & 576,5 \\
\cline { 2 - 3 } & single parent with DDN & \\
\cline { 2 - 3 } & single parent with DS & 594,9 \\
\cline { 2 - 3 } & single parent with 2DD i 2DM & 491,3 \\
\cline { 2 - 3 } & single parent with 2DD & 527,6 \\
\cline { 2 - 3 } & single parent with 2DM & 494,1 \\
\hline \multirow{5}{*}{ Household } & parents with DM & 497,5 \\
\cline { 2 - 3 } & parents with DD & 514,8 \\
\cline { 2 - 3 } & parents with DS & 528,3 \\
\cline { 2 - 3 } & parents with 2 DM & 479,0 \\
\cline { 2 - 3 } & parents with 2 DD & 503,3 \\
\cline { 2 - 3 } & parents with 2 DS & 520,0 \\
\cline { 2 - 3 } & 5-persons & 500,3 \\
\cline { 2 - 3 } & 6-persons & 484,5 \\
\hline Employee household & 1-persons & 701,5 \\
\cline { 2 - 3 } & 2-persons & 553,8 \\
\hline
\end{tabular}

Source: (Haładus, 2019).

The highest Social Intervention Threshold was set for a single-person pensioner household and amounts to PLN 717.3. Among single parents, the lowest threshold was set for a single parent with four children - 491.3 PLN. The lowest threshold among full families is for families with four children - PLN 484.5. The Social Intervention threshold for employee families is lower for 2-person families (female and male) and amounts to PLN 553.8. The Social Intervention threshold for total households is PLN 639.1. 


\section{Conclusion}

In conclusion, it can be stated that the social assistance system in Poland benefits from statistics on the prices of goods and services and the cost of living of households according to the number of households and their age. Thanks to these data, it is possible to determine the value of the minimum subsistence level, the minimum subsistence level, the WDR threshold and the Social Intervention Threshold. The values of these indicators are set in different time horizons - the minimum subsistence level on a monthly basis, and the GVA level once every 3 years. In this way, the state authorities determine the income criterion entitling to receive individual social assistance benefits.

\section{References}

1. Auleytner, J. (2004). Polska polityka spoleczna. Warszawa: WSP.

2. Bochenek, M. (2018). Przyznawanie $i$ wyptacanie świadczeń rodzinnych. Warszawa: Wolters Kluwer.

3. Brągiel, J., Badora, S. (2008). Formy opieki, wychowania $i$ wsparcia $w$ zreformowanym systemie pomocy społecznej. Opole: Uniwersytet Opolski.

4. Broda-Wysocki, P. (2016). Pomoc spoleczna w Polsce-koncepcja i instrument. Warszawa: EAPN Polska.

5. Czajka, Z. (2019). Kompetencje pracowników pomocy społecznej w świetle świadczonych usług. Polityka Społeczna, 46, 18-24.

6. Firlit-Fesnak, G., Szylko-Skoczny, M. (2017). Polityka Społeczna. Warszawa, PWE.

7. Flaszyńska, E. (2018). Bezrobocie, bezrobotny, praca socjalna. Warszawa: Difin.

8. Grebski, M., Wolniak, R., Grebski, W. (2019). Nowa imigracja w północno-wschodniej części Pensylwanii. Szanse i zagrożenia. Systemy Wspomagania w Inżynierii Produkcji, 1, 9-16.

9. Hąbek, P., Wolniak, R. (2013). Analysis of approaches to CSR reporting in selected European Union countries. International Journal of Economics and Research, 4(6), 79-95.

10. Hąbek, P., Wolniak, R. (2016a). Assessing the quality of corporate social responsibility reports: the case of reporting practices in selected European Union member states. Quality \& Quantity, 50(1), 339-420.

11. Hąbek, P., Wolniak, R. (2016b). Factors influencing the development of CSR reporting practices: experts' versus preparers' points of view. Engineering Economy, 26(5), 560-570.

12. Hąbek, P., Wolniak, R. (2016c). Relationship between management practices and quality of CSR reports. Procedia - Social and Behavioral Sciences, 220, 115-123. 
13. Haładus, A. (2019). Systemy pomocy społecznej w Polce. Praca magisterska napisana pod kierunkiem naukowym R. Wolniaka. Katowice.

14. Hys, K., Wolniak, R. (2018). Praktyki przedsiębiorstw przemysłu chemicznego w Polsce w zakresie CSR. Przemyst Chemiczny, 9, 1000-1002.

15. Jachowicz, A. (2015). Funkcjonowanie pomocy społecznej. Dąbrowa Górnicza: WSB.

16. Kamiński, T. (2015). Gminna pomoc społeczna - ćwierć wieku transformacji. Przegląd Politologiczny, 4, 107-117.

17. Kokoszkiewicz, A. (2015). Opieka społeczna jako zadanie państwa. Lublin: Wydawnictwo Europejskiej Fundacji Przedsiębiorczości.

18. Kołaczkowski, B., Ratajczak, M. (2014). Pomoc społeczna. Wybrane instytucje pomocy rodzinie i dziecku. Warszawa: Wolters Kluwer.

19. Lewandowska, A. (2018). Ekonomia społeczna jako skuteczny instrument reintegracji społeczno-zawodowej. Europa Regionum, 36, 37-55.

20. Łojko, M. (2015). Pomoc społeczna wczoraj i dziś. Nowe wyzwania - stare problem. Pomoc Społeczna Wczoraj i Dziś, 11.

21. Łojko, M. (2017). Pomoc społeczna jako instytucja publiczna w obszarze bezrobocia, Polityka Spoleczna, 2, 19-24.

22. Machelski, T. (2017). Bezwarunkowy dochód podstawowy - refleksja prakseologiczna. Studia BAS, 2, 93-106.

23. Maciejko, W. (2015). Świadczenia rodzinne. Warszawa: C.H. Beck.

24. Muszalski, W. (2015). Prawo socjalne. Warszawa: PWN.

25. Olkiewicz, M., Wolniak, R., Grebski, E.M., Olkiewicz, A. (2019). Comparative analysis of the impact of the business incubator center on the economic sustainable development of regions in USA and Poland. Sustainability, 1(173), 1-22.

26. Pląsek, R. (2016). Pomoc społeczna i świadczenia rodzinne w Polsce - narzędzia włączającej zmiany czy utrwalania nierówności społecznych? Uniwersyteckie Czasopismo Socjologiczne, 14, 58-64.

27. Ponomarenko, T.V., Wolniak, R., Marinina, O.A. (2016). Corporate Social responsibility in coal industry (Practices of russian and european companies). Journal of Mining Institute, 222, 882-891.

28. Rajski, G. (2016). Pomoc społeczna w praktyce. Gdańsk: ODDK.

29. Raport Poziom i struktura minimum socjalnego we wrześniu 2018 r. (2018). Warszawa: Instytut Pracy i Spraw Socjalnych.

30. Raport Wartość i struktura Wsparcia Dochodowego Rodzin (2018). Warszawa: Instytut Pracy i Spraw Socjalnych.

31. Staręga-Piasek, J. (2016). Bilans potrzeb pomocy społecznej. Warszawa: IRSS.

32. Szarfenberg, R. (2016). Regionalne ośrodki polityki społecznej. Warszawa: Uniwersytet Warszawski. 
33. Szyszka, M. (2014). Podręcznik wdrażania modelu wspótpracy instytucji z obszaru pomocy społecznej. Bielsko-Biała: Wyższa Szkoła Administracji.

34. Walc, W., Szluz, B. (2008). Opieka i pomoc społeczna wobec wyzwań wspótczesności. Rzeszów.

35. Wolniak, R., Grebski, M.E., Skotnicka-Zasadzień, B. (2019). Comparative analysis of the level of satisfaction with the services received at the business incubators (Hazleton, PA, USA and Gliwice, Poland). Sustainability, 10, 2889, 1-22.

36. Wolniak, R. (2013). The role of Grenelle II in Corporate Social Responsibility integrated reporting. Manager, 17(1), 7-21.

37. Wolniak, R. (2016a). Relations between corporate social responsibility reporting and the concept of greenwashing. Zeszyty Naukowe Politechniki Ślaskiej. Seria Organizacji i Zarządzanie, 87, 443-453.

38. Wolniak, R. (2016b). The relations between uncertainly avoidance and the concept of corporate social responsibility. Zeszyty Naukowe Politechniki Ślaskiej. Seria Organizacji i Zarzadzanie, 91, 291-307.

39. Wolniak, R. (2017a). Problematyka greenwashingu w aspekcie przemysłu 4.0. In: A. Kuzior (ed.), Rozważania różnorodne. Konferencja Rybnik. Zabrze: Śląskie Centrum Etyki Biznesu i Zrównoważonego Rozwoju, 83-93.

40. Wolniak, R. (2017b). Selected problems of professional career development of employees. Zeszyty Naukowe Wyższej Szkoły Humanitas, Zarządzanie, 2, 9-20.

41. Wolniak, R. (2017c). The Corporate Social Responsibility practices in mining sector in Spain and in Poland - similarities and differences. Zeszyty Naukowe Politechniki Ślaskiej. Seria Organizacji i Zarządzanie, 111, 111-120.

42. Wolniak, R. (2018a). Functioning of social welfare on the example of the city of Lazy. Zeszyty Naukowe Wyższej Szkoły, Humanitas. Zarzadzanie, 3, 159-176.

43. Wolniak, R. (2018b). Methods of recruitment and selection of employees on the example of the automotive industry. Zeszyty Naukowe Politechniki Ślaskiej. Seria Organizacja $i$ Zarzadzanie, 128, 475-483.

44. Wolniak, R., Grebski, M.E. (2018). Innovativeness and creativity as factors in workforce development - perspective of psychology. Zeszyty Naukowe Politechniki Ślaskiej. Seria Organizacja i Zarzadzanie, 116, 203-214.

45. Wolniak, R., Grebski, M.E. (2018). Innovativeness and creativity as nature and nurture. Zeszyty Naukowe Politechniki Ślaskiej. Seria Organizacja i Zarzadzanie, 116, 215-226.

46. Wolniak, R., Grebski, M.E. (2018). Innovativeness and Creativity of the Workforce as Factors Stimulating Economic Growth in Modern Economies. Zeszyty Naukowe Politechniki Ślaskiej. Seria Organizacja i Zarządzanie, 116, 227-240.

47. Wolniak, R., Hąbek, P. (2016). Quality assessment of CSR reports - factor analysis. Procedia - Social and Behavioral Sciences, 220, 541-547. 
48. Wolniak, R., Skotnicka-Zasadzień, B. (2018). Developing a model of factors influencing the quality of service for disabled customers in the condition s of sustainable development, illustrated by an example of the Silesian Voivodeship public administration. Sustainability, 7, 1-17.

49. www.ipiss.gov.pl, 14.01.2020. 